\title{
Can sulphur improve the nutrient uptake, partitioning, and seed yield of sesame?
}

\author{
Muhammad Zeeshan Mehmood ${ }^{1} \cdot$ Obaid Afzal $^{1} \cdot$ Mukhtar Ahmed $^{1,2} \cdot$ Ghulam $^{\text {Qadir }}{ }^{1} \cdot$ Ahmed M.S. Kheir $^{3,4}$. \\ Muhammad Aqeel Aslam ${ }^{1} \cdot$ Atta Mohi Ud Din ${ }^{5} \cdot$ Imran Khan $^{6} \cdot$ Muhammad Jawad Hassan $^{6} \cdot$ Tehseen Ahmad Meraj $^{5}$. \\ Muhammad Ali Raza ${ }^{5}$. Shakeel Ahmad ${ }^{7}$
}

Received: 5 February 2021 / Accepted: 29 April 2021 / Published online: 14 May 2021

(C) The Author(s) 2021

\begin{abstract}
Sulphur (S) is considered to improve the nutrient uptake of plants due to its synergistic relationship with other nutrients. This could ultimately enhance the seed yield of oilseed crops. However, there is limited quantitative information on nutrient uptake, distribution, and its associated impacts on seed yield of sesame under the $\mathrm{S}$ application. Thus, a two-year field study (2018 and 2019) was conducted to assess the impacts of different $S$ treatments $\left(S_{0}=\right.$ Control, $S_{20}=20, S_{40}=40$, and $\left.S_{60}=60 \mathrm{~kg} \mathrm{ha}^{-1}\right)$ on total dry matter production, nitrogen, phosphorus, potassium, $\mathrm{S}$ uptake and distribution at the mid-bloom stage and physiological maturity. Furthermore, treatment impacts were studied on the number of capsules per plant, number of seeds per capsule, thousand seed weight, and seed yield at physiological maturity in sesame. Compared to $\mathrm{S}_{0}$, over the years, treatment $\mathrm{S}_{40}$ significantly increased the total uptake of nitrogen, phosphorus, potassium, and $\mathrm{S}$ (by 13, 22, $11 \%$ and $16 \%$, respectively) at physiological maturity, while their distribution by $13,36,14$, and $24 \%$ (in leaves), 12, 15, 11, and $15 \%$ (in stems), 15, 42, 18, and $10 \%$ (in capsules), and 14, 22, 9, and 15\% (in seeds), respectively. Enhanced nutrient uptake and distribution in treatment $\mathrm{S}_{40}$ improved the total biomass accumulation (by 28\%) and distribution in leaves (by 34\%), stems (by 27\%), capsules (by 26\%), and seeds (by $28 \%$ ), at physiological maturity, as compared to $\mathrm{S}_{0}$. Treatment $\mathrm{S}_{40}$ increased the number of capsules per plant (by $13 \%$ ), number of seeds per capsule (by $11 \%$ ), and thousand seed weight (by $6 \%$ ), compared to $\mathrm{S}_{0}$. Furthermore, over the years, relative to control, sesame under $\mathrm{S}_{40}$ had a higher seed yield by $28 \%$ and enhanced the net economic returns by $44 \%$. Thus, our results suggest that optimum $\mathrm{S}$ level at the time of sowing improves the nutrient uptake and distribution during the plant lifecycle, which ultimately enhances total dry matter accumulation, seed yield, and net productivity of sesame.
\end{abstract}

Keywords Sesame $\cdot$ Sulphur $\cdot$ Nutrient uptake $\cdot$ Seed yield $\cdot$ Economics

\section{Introduction}

Oilseeds are important crops that play a prominent role in the agriculture industry all over the globe. The oil obtained

Responsible Editor: Haroun Chenchouni

Mukhtar Ahmed

ahmadmukhtar@uaar.edu.pk; mukhtar.ahmed@slu.se

1 Department of Agronomy, PMAS-Arid Agriculture University Rawalpindi, Rawalpindi 46000, Pakistan

2 Department of Agricultural Research for Northern Sweden, Swedish University of Agricultural Sciences, 90183 Umeå, Sweden

3 Haikou Experimental Station, Chinese Academy of Tropical Agricultural Sciences (CATAS), Haikou, China through these oilseed crops is the major constituent of the human diet and an important source of healthy fatty acids to meet human dietary needs (Zargar et al. 2016; Abiodun 2017). However, the rapidly increasing population of the world,

4 Soils, Water and Environment Research Institute, Agricultural Research Center, 9 Cairo University Street, Giza, Egypt

5 College of Agronomy, Sichuan Agricultural University, Chengdu 611130, China

6 Department of Grassland Science, Animal Science and Technology College, Sichuan Agricultural University, Chengdu 611130, China

7 Department of Agronomy, Bahauddin Zakariya University, Multan 60800, Pakistan 
clearly indicates that demand for high-quality oilseeds continues to grow (Islam et al. 2016). Likewise, over the past three decades, increased interest in oilseeds led to an $82 \%$ expansion in the total cultivated area (Rahman and Dejiménez 2016). Consequently, this continuous intensification and extension in cropping areas are exerting pressure on agricultural land and resulting in overexploitation of the natural resources, which is a major concern in agricultural sustainability (FAO 2017). Thus, to satisfy the growing demands of edible oils, oilseeds production needs to be coupled with efficient agronomic practices to increase the per unit area yield on a sustainable basis.

Sulphur (S) is considered a key element in plant nutrition and oilseed crops may not reach their full potential when it becomes a limiting factor. Because it affects the developmental processes (such as capsule initiation) in plants (Girondé et al. 2014). Hence, high seed yield and quality of oilseeds are possible when they have access to the optimum amount of S (Scherer 2001). It also increases the uptake of major plant nutrients, namely, nitrogen $(\mathrm{N})$, phosphorus $(\mathrm{P})$, and potassium $(\mathrm{K})$, while reducing the uptake of toxic elements such as chlorine and sodium (Zhang et al. 1999; Salvagiotti et al. 2009). Furthermore, studies have documented that $S$ application improves sesame seed yield, oil, and protein contents (Raza et al. 2018a, 2018b). However, these investigations have not quantified the effects of S application on the nutrient uptake and distribution in sesame crop. Therefore, $\mathrm{S}$ fertilization can show promising results in improving the nutrient uptake, biomass accumulation, and seed yield of sesame.

$\mathrm{N}, \mathrm{P}, \mathrm{K}$, and $\mathrm{S}$ are the key macronutrients that drive the growth and developmental processes of crops (Scherer 2001; Raza et al. 2019). Adequate availability and uptake of these essential nutrients influence the synthesis and distribution of carbohydrates in plants (Arduini et al. 2006). The optimum quantity of $\mathrm{N}$ in crops increases the leaves development and photosynthetic capacity (Muchow and Davis 1988), and also improves the biomass accumulation and distribution towards the reproductive organs of the crop plants (Vouillot and Devienne-Barret 1999; Prystupa et al. 2004). P influences the dry matter accumulation and distribution in vegetative as well as reproductive parts in a different way than $\mathrm{N}$ (Batten 1992; Prystupa et al. 2004) and affects the seed yield and yield components of crops (Elliott et al. 1997). Similarly, optimum uptake of $\mathrm{K}$ is essential for improving crop production, Iqbal and Hidayat (2016) revealed that adequate K significantly enhances crop growth, dry matter accumulation, and partitioning in economic plant parts such as seeds. Moreover, nutrient uptake depends on the crop type, cultivar, and microenvironment but it is more influenced by the growing conditions (such as nutrient availability) in field rather than any other factor (Raza et al. 2019). Hence, understanding the nutrient uptake of the crop is critical for sustainable agricultural production. However, past investigations neglected the role and importance of nutrient uptake and distribution in sesame productivity. Besides, studies have not focused on the effects of S application on nutrient accumulation and distribution of sesame.

The S deficiency in oilseeds adversely impacts the seed yield and quality because it reduces the carbohydrates translocation to the reproductive parts and utilization for oil synthesis (Rani et al. 2009; Sahoo et al. 2018). In recent decades, reports on $\mathrm{S}$ deficiency have increased due to reduction in soil fertility status and organic matter content as a result of intensive agriculture and low $\mathrm{S}$ containing fertilizers as a result of strict sulphur dioxide emissions control (Eriksen 2009; Steinke et al. 2015; Carciochi et al. 2016). However, S application has been reported to enhance nutrient uptake and seed yield. Previously, it has been confirmed that $\mathrm{S}$ application contributes towards better nutrients uptake and carbohydrate synthesis in the crop plants due to synergistic effects with other nutrients such as N, P, and K (Haneklaus et al. 2007; Carciochi et al. 2020). Furthermore, past improvements in crop yields were associated with enhanced nutrients accumulation and distribution because these nutrients are essential seed components (Sinclair et al. 2019), whereas, the effects of S application on N, P, K, and S uptake and distribution were not studied before in sesame. Hence, adequate $\mathrm{S}$ availability is a key factor in sesame production and there is insufficient knowledge about the potential benefits of S application on nutrient uptake and distribution in sesame plants.

Therefore, in this study, we investigated the effects of $\mathrm{S}$ application on major plant nutrients uptake (at the mid-bloom and physiological maturity stages) and seed yield (at physiological maturity) of sesame under the rainfed conditions. The key objectives of this field study were to (1) assess the impact of $\mathrm{S}$ application on dry matter production, $\mathrm{N}, \mathrm{P}, \mathrm{K}$, and $\mathrm{S}$ uptake, and their distribution in sesame plants (at the midbloom and physiological maturity); (2) study the influence of S application on yield components and seed yield of sesame (at physiological maturity), and (3) evaluate the effects of S application on economic returns of sesame.

\section{Material and methods}

\section{Site description}

This field experiment was conducted during the growing seasons of 2018 and 2019 at the research farm $\left(33^{\circ} 11^{\prime} 62^{\prime \prime} \mathrm{N}\right.$, $73^{\circ} 00^{\prime} 99^{\prime \prime}$ E, 520 m elevation) of PMAS-Arid Agriculture University Rawalpindi in Punjab Province, Pakistan (Fig. 1). The climate of the research site falls under the dry sub-humid region with monsoon-influenced high summer rainfall (mainly in July and August). Monthly rainfall, average maximum, 


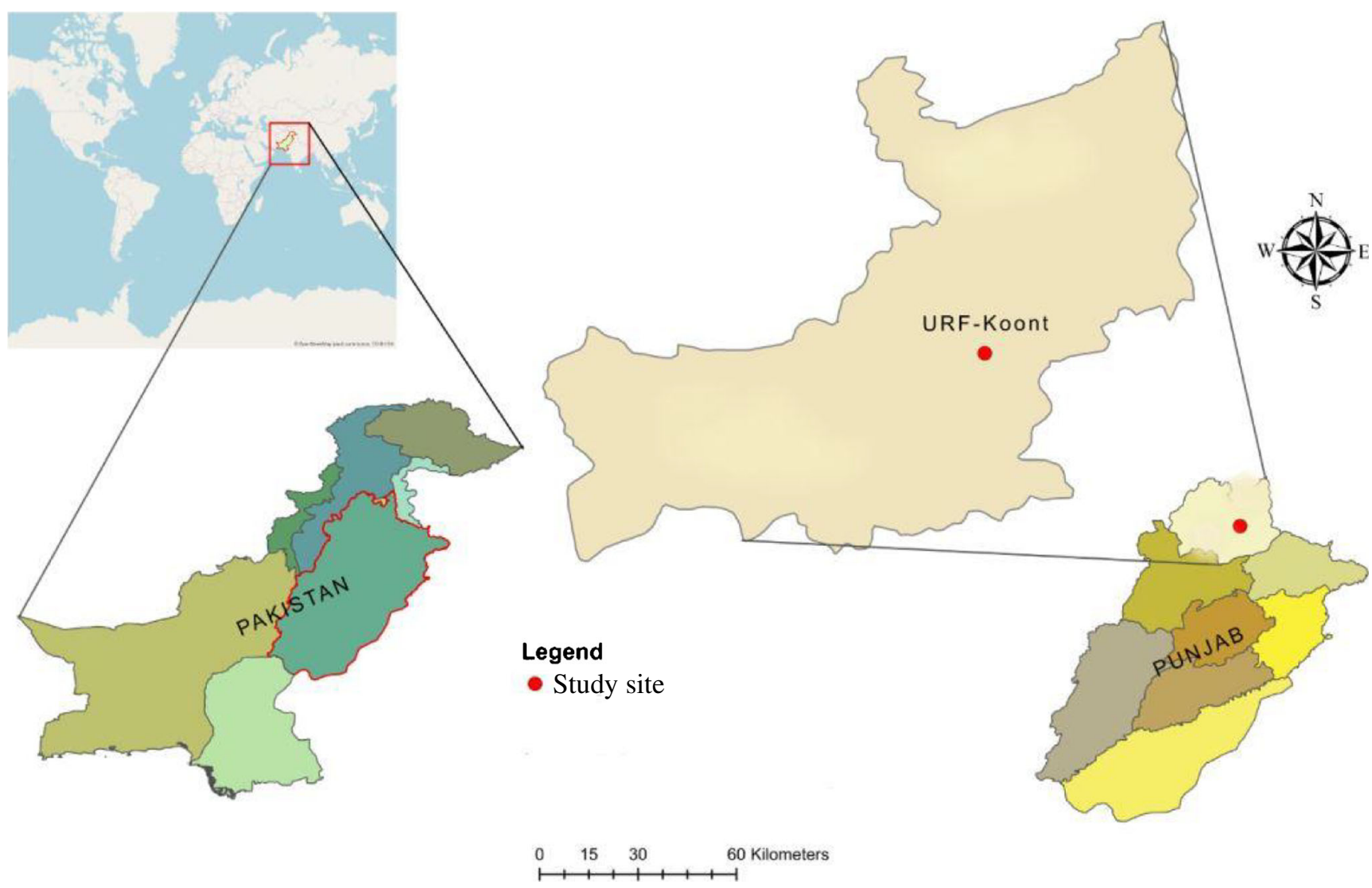

Fig. 1 Location of the study site

and minimum temperature during growing seasons in 2018 and 2019 are given in Fig. 2. For soil testing and analysis, procedures of ICARDA Manual "Soil Plant and Water Analysis" were followed (Estefan et al. 2013), i.e., pH meter for soil pH, EC meter for soil electrical conductivity, Kjeldahl Method for soil available N, Olsen's method for soil available P, Flame Atomic Absorption Spectrophotometry Method for soil available K, Turbidimetric method for soil available S, Walkley-Black method for soil organic matter, saturation paste percentage method for soil saturation, and excavation method of distributed soil samples for soil bulk density. According to the soil tests at the time of sowing, the top soil layer of $20 \mathrm{~cm}$ had loam texture with $\mathrm{pH}$ (7.2), electrical conductivity $\left(1.02 \mathrm{dSm}^{-1}\right)$, available $\mathrm{N}\left(0.28 \mathrm{~g} \mathrm{~kg}^{-1}\right)$, available $\mathrm{P}\left(2.5 \mathrm{~g} \mathrm{~kg}^{-1}\right)$, available $\mathrm{K}\left(95 \mathrm{~g} \mathrm{~kg}^{-1}\right)$, available $\mathrm{S}(4.3 \mathrm{~g}$ $\left.\mathrm{kg}^{-1}\right)$, organic matter $(0.57 \%)$, saturation $(34 \%)$, and bulk density $\left(1.23 \mathrm{~g} \mathrm{~cm}^{-3}\right)$.

\section{Experimental design and details}

The experiment was executed in RCBD-factorial design with three replicates. This field study had two sesame cultivars (TS-5 and TS-3) and four S levels $\left(\mathrm{S}_{0}=\right.$ Control, $\mathrm{S}_{20}=20$,
$\mathrm{S}_{40}=40$, and $\mathrm{S}_{60}=60 \mathrm{~kg} \mathrm{ha}^{-1}$ ) as treatments. Seed of sesame cultivars was collected from Ayub Agriculture Research Institute (AARI), Faisalabad. Both cultivars, namely, TS-5 and TS-3 were high yielding and branched with the genetic potential of $2346 \mathrm{~kg} \mathrm{ha}^{-1}$ and $2214 \mathrm{~kg} \mathrm{ha}^{-1}$ (AARI). While S was applied as a basal dose at the time of sowing and ammonium sulphate was used as a source of $\mathrm{S}$. The size of each plot was $5 \mathrm{~m}$ wide and $6 \mathrm{~m}$ long $\left(30 \mathrm{~m}^{2}\right)$, and the total area was 720 $\mathrm{m}^{2}\left(30 \mathrm{~m}^{2} \times 24\right.$ plots $)$. Sesame was sown during the first week of July in 2018 and 2019 while harvested during the second week of November in 2018 and 2019. The sesame seeds were sown manually with a hand-operated seed drill at the seeding depth of $2 \mathrm{~cm}$. The distance between the plants and rows was maintained at 10 and $45 \mathrm{~cm}$, respectively, which resulted in a plant population of 200,000 plants $\mathrm{ha}^{-1}$. The fertilizers were applied as basal dose at the time of sowing, at the rate of $\mathrm{N}$ $50 \mathrm{~kg} \mathrm{ha}^{-1}, \mathrm{P} 60 \mathrm{~kg} \mathrm{ha}^{-1}$, K was not applied because the soil at the study site had adequate $\mathrm{K}$-content and $\mathrm{S}$ was applied as per treatment. Urea and diammonium phosphate were used as sources of $\mathrm{N}$ and $\mathrm{P}$. No supplemental irrigation was given during the growing period of the crop and it was completely dependent on rainfall. All other recommended practices were kept uniform in all experimental units. 

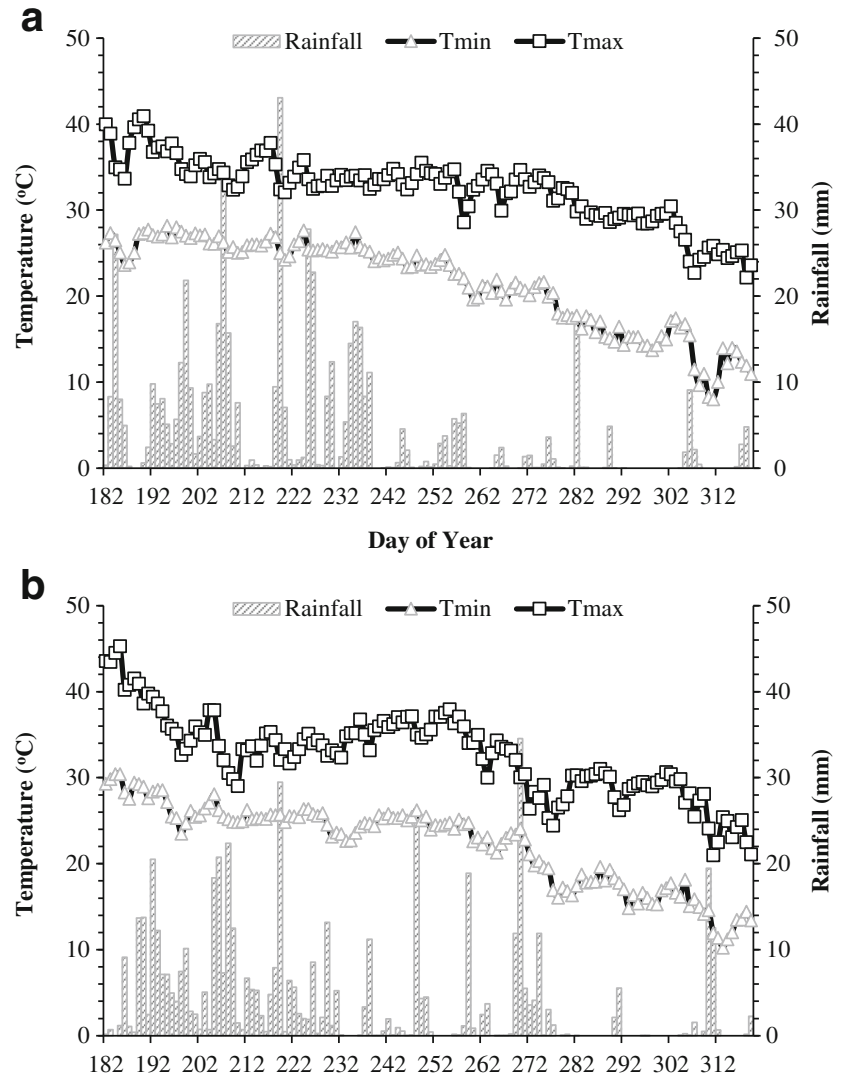

Day of Year

Fig. 2 Mean maximum and minimum temperature, and rainfall during the growing season of sesame in 2018 and 2019

\section{Measurements}

For sampling, measurements, and analysis of dry matter production and distribution, nutrient uptake and distribution, and seed yield, two sesame growth stages (mid bloom (MB) $(65$ days after sowing) and physiological maturity (PM) (125 days after sowing)) were selected following the previously published phenological scale (Langham 2007).

\section{Dry matter production and distribution}

For dry matter production $\left(\mathrm{kg} \mathrm{ha}^{-1}\right)$ and distribution in leaves, stem, capsule, and seeds $\left(\mathrm{g} \mathrm{m}^{-2}\right)$ analysis, fifteen consecutive plants of sesame, from central rows of each plot were manually harvested with sickles at MB and PM stages. Then, all the collected plant samples were separated into leaves, stem, and capsules (at MB), and leaves, stem, capsules, and seed (at $\mathrm{PM}$ ). At each stage, all the plant organ samples were ovendried at $70^{\circ} \mathrm{C}$ to attain a constant dry weight and then the dry matter for each plant organ was presented as grams per meter square. The total dry matter (TDM) production was calculated as the product of dry matter per meter square and the number of meter squares per hectare.
Nutrient uptake and distribution

At MB and PM, after the determination of the dry matter production, the same samples (leaves, stem, capsules, and seeds) were utilized for the measurement of $\mathrm{N}, \mathrm{P}, \mathrm{K}$, and $\mathrm{S}$ contents in the plant organs. For the preparation of samples to determine the nutrient contents, each plant organ sample was ground by using a Wiley Mill, passed through a $0.5 \mathrm{~mm}$ sieve, and then sample digestion was carried out using Nitric acid $\left(\mathrm{HNO}_{3}\right)$ and hydrogen peroxide $\left(\mathrm{H}_{2} \mathrm{O}_{2}\right)$. Then N-content $(\mathrm{g}$ plant $^{-1}$ ) of each organ sample was measured using the Kjeldahl procedure ( $\mathrm{Li}$ et al. 2001), P-content $\left(\mathrm{g}_{\text {plant }}{ }^{-1}\right.$ ) of each organ sample was determined using the Vanadomolybdate method (Xia et al. 2013), K-content (g plant $^{-1}$ ) of each organ sample was estimated using the Flame Atomic Absorption Spectrophotometry Method and S-content (g plant ${ }^{-1}$ ) of each organ sample was measured using the Turbidimetric method (Verma et al. 1977). The N, $\mathrm{P}, \mathrm{K}$, and $\mathrm{S}$ accumulation was determined as the product of dry matter in each plant organ and N, P, K, and S concentration in each plant organ, and presented as kilograms per hectare. The total N, P, K, and S uptake was calculated by the summation of $\mathrm{N}, \mathrm{P}, \mathrm{K}$, and $\mathrm{S}$ contents in all the plant organs.

\section{Seed yield}

For seed yield and yield components, twenty sesame plants from central rows of each plot were manually harvested using shears, at physiological maturity. Harvested samples were then sun-dried in the form of bundles for one week by keeping the plants in a vertical direction. After drying, plants were threshed manually to determine the seed yield $\left(\mathrm{kg} \mathrm{ha}^{-1}\right)$ and yield components including the number of capsules (plant ${ }^{-1}$ ), number of seeds (capsule ${ }^{-1}$ ), and thousand seed weight $(\mathrm{g})$.

\section{Economic analysis}

The economic analysis, using partial budgeting was performed to determine the economic viability of $\mathrm{S}$ application for sesame production. The total cost of production included all the expenses from sowing to harvesting of the crop were estimated depending on the local rates, while the gross income was estimated based on the local market prices of sesame, and net income was calculated from the subtraction of total cost from the obtained gross income (Raza et al. 2018b).

\section{Statistical analysis}

Statistical analysis of the data was performed using Statistix 8.1 software. Significant differences among the studied cultivars and $\mathrm{S}$ levels were computed through the Analysis of Variance (ANOVA) technique in combination with the Least Significant Difference (LSD) test. The significance of 
the computed differences between means was evaluated at a $5 \%$ probability level $(p<0.05)$. Graphical representation of the data was made using the Microsoft Excel program.

\section{Results}

\section{Dry matter production and distribution}

The dry matter production and distribution within sesame plants under different $\mathrm{S}$ treatments at $\mathrm{MB}$ and $\mathrm{PM}$ are shown in Table 1. Across the different $\mathrm{S}$ treatments and sampling stages, on average over the years, sesame plants produced dry matter of $4357.8 \mathrm{~kg} \mathrm{ha}^{-1}$ and $6440.1 \mathrm{~kg} \mathrm{ha}^{-1}$ in $\mathrm{S}_{0}$, $4613.0 \mathrm{~kg} \mathrm{ha}^{-1}$ and $7011.1 \mathrm{~kg} \mathrm{ha}^{-1}$ in $\mathrm{S}_{20}, 5654.1 \mathrm{~kg} \mathrm{ha}^{-1}$ and $8239.8 \mathrm{~kg} \mathrm{ha}^{-1}$ in $\mathrm{S}_{40}$, and $4887.8 \mathrm{~kg} \mathrm{ha}^{-1}$ and $7660.8 \mathrm{~kg} \mathrm{ha}^{-1}$ in $\mathrm{S}_{60}$, at $\mathrm{MB}$ and $\mathrm{PM}$, respectively. Different $\mathrm{S}$ levels not only influenced the dry matter production but also altered the distribution patterns in the plant part of the sesame (Table 1). For example, across the years, compared to $\mathrm{S}_{0}$, treatment $\mathrm{S}_{40}$ improved the biomass in leaves, stem, and capsules by 27, 29, and 35\%, respectively, at MB. Moreover, optimum $\mathrm{S}$ level in $\mathrm{S}_{40}$ significantly increased the dry matter by $28 \%$, and dry matter contents in leaves by $34 \%$, stem by $27 \%$, capsules by $26 \%$, and seeds by $28 \%$ at PM in comparison with $\mathrm{S}_{0}$, indicating that $\mathrm{S}$ application significantly enhanced the source size which improved the biomass accumulation and distribution in economic parts (capsules and seeds).

\section{N-uptake}

Table 2 shows the total N-uptake and N-contents in different plant organs of sesame in different $\mathrm{S}$ treatments. On average, the highest nitrogen uptake (58.4 and $94.4 \mathrm{~kg} \mathrm{ha}^{-1}$, at MB and $\mathrm{PM}$, respectively) was observed in $\mathrm{S}_{40}$ while the lowest $\mathrm{N}$ uptake (51.2 and $83.6 \mathrm{~kg} \mathrm{ha}^{-1}$, at MB and PM, respectively) was found in $\mathrm{S}_{0}$. We also measured the nitrogen contents in leaves, stems, capsules, and seeds of sesame understudied $\mathrm{S}$ treatments. Our results suggested that the N-contents of sesame leaves, stem, capsules, and seeds were highest at MB and $\mathrm{PM}$ in $\mathrm{S}_{40}$ among all the treatments. On average, at $\mathrm{MB}$, the maximum $\mathrm{N}$-content in leaves, stems, and capsules (28.2, 14.0 , and $16.4 \mathrm{~kg} \mathrm{ha}^{-1}$, respectively) were obtained in $\mathrm{S}_{40}$ whereas the minimum $\mathrm{N}$-content in leaves, stems, and capsules $\left(24.7,12.2\right.$, and $14.3 \mathrm{~kg} \mathrm{ha}^{-1}$, respectively) were noted in $\mathrm{S}_{0}$. Similarly, at $\mathrm{PM}$, the average highest $\mathrm{N}$-content in leaves $\left(11.8 \mathrm{~kg} \mathrm{ha}^{-1}\right)$, stem $\left(33.3 \mathrm{~kg} \mathrm{ha}^{-1}\right)$, capsules $\left(6.6 \mathrm{~kg} \mathrm{ha}^{-1}\right)$, and seeds $\left(42.8 \mathrm{~kg} \mathrm{ha}^{-1}\right)$ were observed in $\mathrm{S}_{40}$ while the lowest $\mathrm{N}$-content in leaves $\left(10.4 \mathrm{~kg} \mathrm{ha}^{-1}\right)$, stem $\left(29.8 \mathrm{~kg} \mathrm{ha}^{-1}\right)$, capsules $\left(5.8 \mathrm{~kg} \mathrm{ha}^{-1}\right)$, and seeds $\left(37.7 \mathrm{~kg} \mathrm{ha}^{-1}\right)$ were obtained in $\mathrm{S}_{0}$. Moreover, $\mathrm{N}$ and $\mathrm{S}$ dynamics during this study suggested that their uptake in sesame was closely related to the amount of $\mathrm{S}$ applied, and the maximum uptake was recorded for $\mathrm{S}_{40}$ treatment (Fig. 3).

\section{P-uptake}

Table 3 presents the total P-uptake and P-contents under the studied $\mathrm{S}$ treatments. At MB and PM, the average highest $\mathrm{P}$ uptake of $12.1 \mathrm{~kg} \mathrm{ha}^{-1}$ and $24.3 \mathrm{~kg} \mathrm{ha}^{-1}$ were measured in $\mathrm{S}_{40}$, whereas the average lowest P-uptake of $9.7 \mathrm{~kg} \mathrm{ha}^{-1}$ and $19.9 \mathrm{~kg} \mathrm{ha}^{-1}$ were obtained in $\mathrm{S}_{0}$ treatment. Overall, $\mathrm{S}_{40}$ treatment increased the P-uptake (by 24\%) at MB and (by 22\%) at $\mathrm{PM}$, over the years, as compared to $\mathrm{S}_{0}$. In this experiment, different $\mathrm{S}$ treatments also influenced the $\mathrm{P}$-contents in different plant organs of sesame at MB and PM. On average, at MB, the average maximum P-contents of leaves $\left(4.6 \mathrm{~kg} \mathrm{ha}^{-1}\right)$, stem $\left(6.2 \mathrm{~kg} \mathrm{ha}^{-1}\right)$, and capsules $\left(1.4 \mathrm{~kg} \mathrm{ha}^{-1}\right)$ were measured in $\mathrm{S}_{40}$. Similarly, at PM, the average maximum P-contents in leaves $\left(2.9 \mathrm{~kg} \mathrm{ha}^{-1}\right)$, stem $\left(7.6 \mathrm{~kg} \mathrm{ha}^{-1}\right)$, capsules $(1.7 \mathrm{~kg}$ $\left.\mathrm{ha}^{-1}\right)$, and seeds $\left(12.2 \mathrm{~kg} \mathrm{ha}^{-1}\right)$ were also found in $\mathrm{S}_{40}$. However, the average minimum P-contents in all plant organs, at $\mathrm{MB}$ and $\mathrm{PM}$, were observed in treatment $\mathrm{S}_{0}$. Overall, treatment $\mathrm{S}_{40}$ enhanced the P-content in leaves (by $32 \%$ ), stem (by 17\%), capsules (by $46 \%$ ), and seeds (by $22 \%$ ), as compared to $\mathrm{S}_{0}$ treatment.

\section{K-uptake}

Table 4 shows the total $\mathrm{K}$-uptake and $\mathrm{K}$-contents in various plant parts of sesame under different $\mathrm{S}$ treatments. Different $\mathrm{S}$ treatments significantly affected the K-uptake, and K-contents of sesame. The highest K-uptake at both MB and PM was obtained in treatment $\mathrm{S}_{40}$ while the lowest in K-uptake in treatment $\mathrm{S}_{0}$. On average, across the years, $\mathrm{S}_{40}$ improved the K-uptake (by $13 \%$ at $\mathrm{MB}$ and $11 \%$ at $\mathrm{PM}$ ) compared to $\mathrm{S}_{0}$, (by $6 \%$ at $\mathrm{MB}$ and $4 \%$ at $\mathrm{PM}$ ) compared to $\mathrm{S}_{20}$, and (by $3 \%$ at $\mathrm{MB}$ and $2 \%$ at $\mathrm{PM}$ ) compared to $\mathrm{S}_{60}$. $\mathrm{S}$ treatments also influenced the K-contents at the plant organ level in sesame at both stages, while $\mathrm{S}_{40}$ showed the highest K-contents in different plant organs of sesame. Averaged across the years, $\mathrm{S}_{40}$ increased the K-contents in leaves, stem, capsules, and seeds by $(11 \%$ at $\mathrm{MB}$ and $14 \%$ at $\mathrm{PM}),(12 \%$ at $\mathrm{MB}$ and $11 \%$ at $\mathrm{PM}),(21 \%$ at $\mathrm{MB}$ and $18 \%$ at $\mathrm{PM})$, and (9\% at $\mathrm{PM})$, respectively.

\section{S-uptake}

Table 5 presents the total S-uptake and S-content under different $\mathrm{S}$ treatments. Total S-uptake was significantly influenced by the different $\mathrm{S}$ treatments. Overall, across all the treatments, treatment $\mathrm{S}_{40}$ showed the average highest $\mathrm{S}$ uptake (32.7 $\mathrm{kg} \mathrm{ha}^{-1}$ at MB and $45.6 \mathrm{~kg} \mathrm{ha}^{-1}$ at PM) at both sampling intervals and years. On average, treatments $\mathrm{S}_{40}$ increased the total S-uptake by $21 \%$ at $\mathrm{MB}$ and $16 \%$ at PM, 


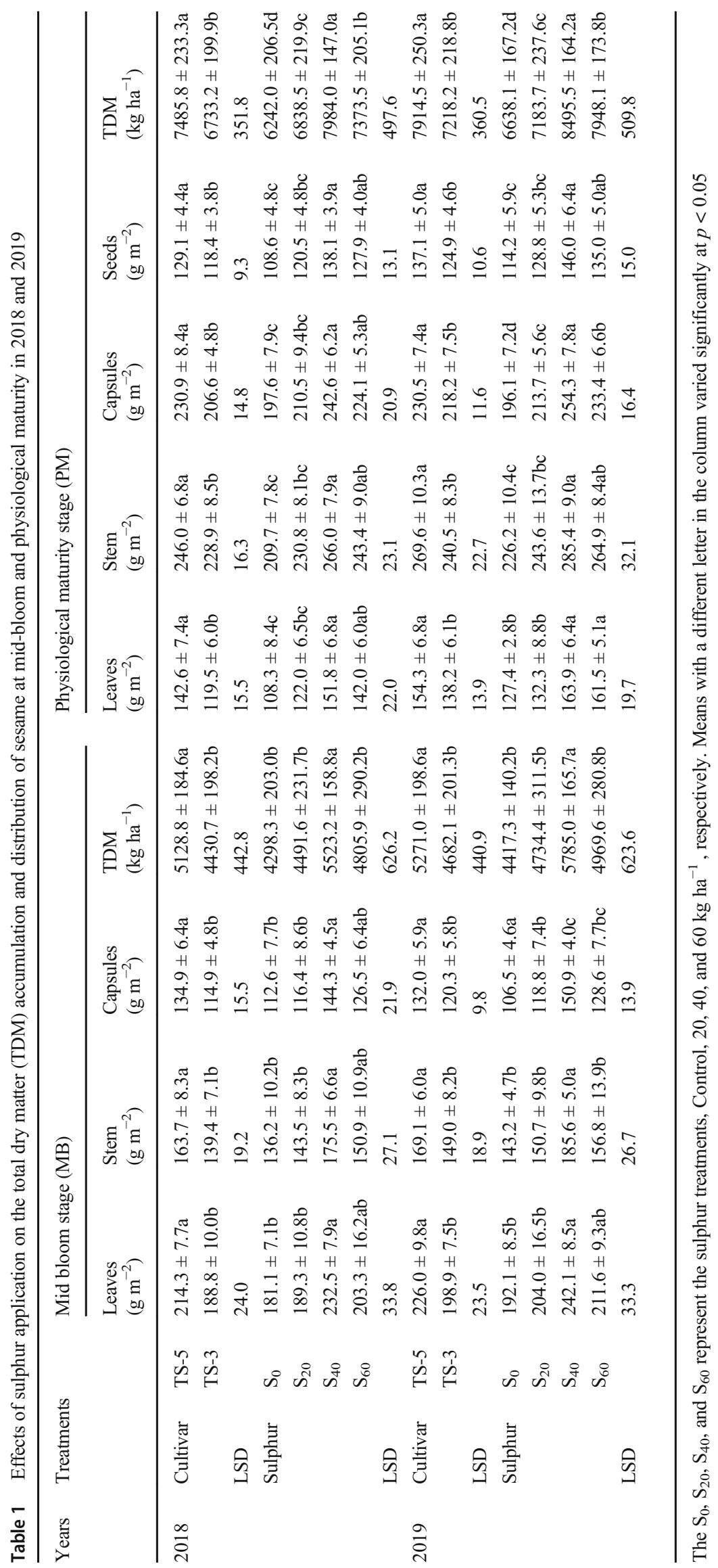




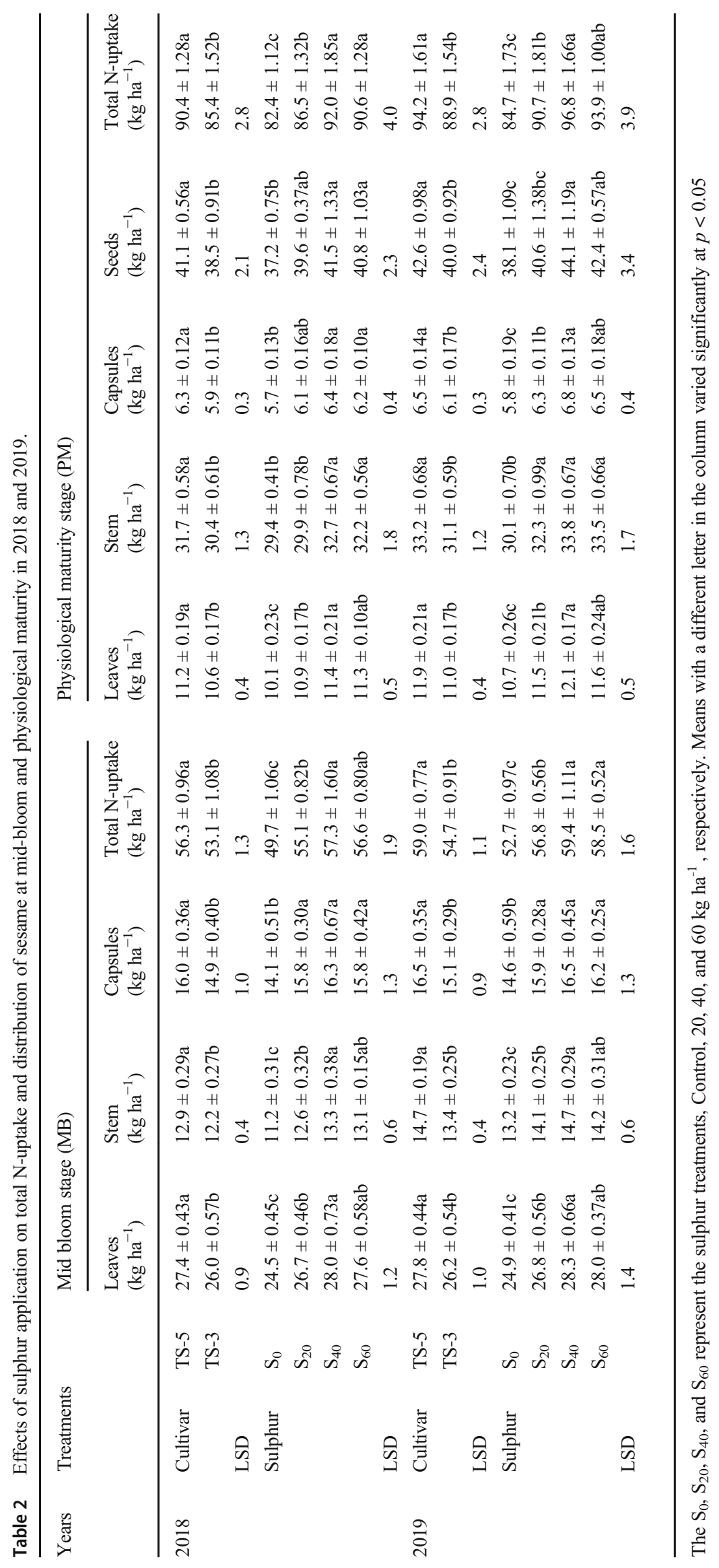


Fig. 3 Total Nitrogen and Sulphur uptake $\left(\mathrm{kg} \mathrm{ha}^{-1}\right)$ in sesame

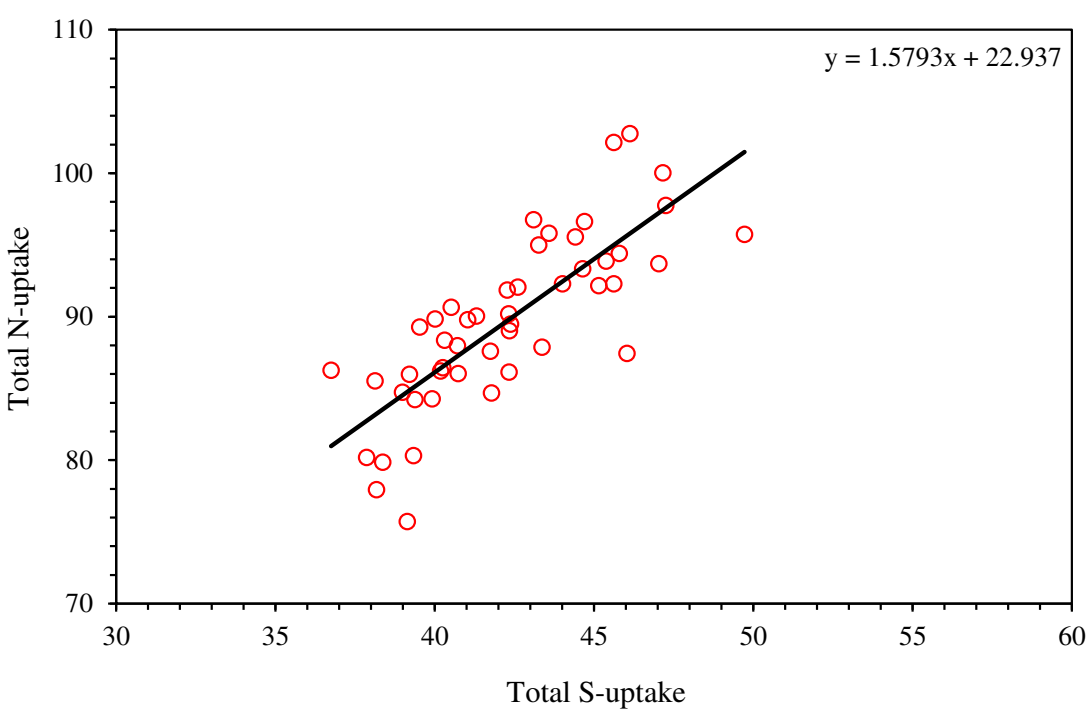

compared to control. Different $\mathrm{S}$ treatments had also affected the S-content in different plant parts of sesame. However, treatment $\mathrm{S}_{40}$ showed the highest S-content in leaves, stem, capsules, and seeds at both MB and PM stages under-studied treatments. Overall, compared to control, treatment $\mathrm{S}_{40}$ increased the S-content in leaves (by 26\%), stem (by 15\%), and capsules (by 20\%) at MB, while in leaves (by 24\%), stem (by 15\%), capsules (by 10\%), and seeds (by 14\%) at PM.

\section{Seed yield and yield components}

Figure 4 presents the influence of different $\mathrm{S}$ treatments on seed yield and yield components of sesame. The sesame yield components including the number of capsules (plant $^{-1}$ ), number of seeds (capsule ${ }^{-1}$ ), and thousand seed weight are given in Fig. 4. During both years of this study, $\mathrm{S}$ treatments exhibited a significant influence on yield components of sesame plants. The average highest number of capsules plant ${ }^{-1}$ (29.5), number of seeds capsule $^{-1}$ (70.9), and thousand seed weight (3.58 g) were noted in $\mathrm{S}_{40}$ treatment, whereas the average lowest number of capsules plant ${ }^{-1}$ (26.2), number of seeds capsule ${ }^{-1}$ (63.9), and thousand seed weight (3.37 g) were recorded in $\mathrm{S}_{0}$. On average, across the years, compared to $\mathrm{S}_{0}$, treatment $\mathrm{S}_{40}$ increased the number of capsules plant ${ }^{-1}$ (by $13 \%$ ), the number of seeds capsule ${ }^{-1}$ (by $11 \%$ ), and thousand seed weight (by 6\%). Moreover, the seed yield of sesame was also significantly influenced by different $\mathrm{S}$ treatments (Fig. 4). The highest seed yield (1396.1 kg $\mathrm{ha}^{-1}$ in 2018 , and $1425.7 \mathrm{~kg} \mathrm{ha}^{-1}$ in 2019) was recorded in $\mathrm{S}_{40}$, while the lowest (1086.3 $\mathrm{kg} \mathrm{ha}^{-1}$ in 2018 , and $1135.8 \mathrm{~kg} \mathrm{ha}^{-1}$ in 2019) seed yield was recorded in $\mathrm{S}_{0}$ treatment. Overall, across the years, relative to $\mathrm{S}_{0}$, treatment $\mathrm{S}_{40}$ enhanced the sesame seed yield by $28 \%$, however, relative to $\mathrm{S}_{40}$, excessive $\mathrm{S}$ application in $\mathrm{S}_{60}$ decreased the sesame yield by $8 \%$.

\section{Economic analysis}

The economic analysis under different $S$ treatments for sesame production is given in Table 6 . In this study, the average maximum total income of sesame was observed in treatment $\mathrm{S}_{40}$, and the average minimum total income of sesame was recorded in $\mathrm{S}_{0}$. On average, over the years, compared to $\mathrm{S}_{0}$, the net income was increased by $21 \%$ under $\mathrm{S}_{20}$ treatment, $44 \%$ in $\mathrm{S}_{40}$ treatment, and $29 \%$ in $\mathrm{S}_{60}$ treatment.

\section{Discussion}

The improvements in resource utilization efficiency of plants require a multifaceted approach and could enhance the dry matter and nutrient accumulation as well as translocation towards the economic plant parts. This experiment showed that different $\mathrm{S}$ levels at the mid-bloom and physiological maturity had significant impacts on dry matter production and partitioning, nutrient uptake and partitioning, and seed yield of sesame. Overall, optimum S availability at $40 \mathrm{~kg} \mathrm{ha}^{-1}$ for sesame in $\mathrm{S}_{40}$, as compared with $\mathrm{S}_{0}$, increased the total dry matter $(+29 \%)$, seed yield $(+28 \%)$, and enhanced the $\mathrm{N}$ uptake $(+13 \%)$, P-uptake $(+22 \%)$, K-uptake $(+11 \%)$ and Suptake $(+16 \%)$ in sesame. This study demonstrated that an optimum dose of $\mathrm{S}$ allowed better $\mathrm{S}$ availability to sesame plants which improved the nutrients uptake, total dry matter production, and ultimately enhanced the seed yield of sesame.

Dry matter production and distribution in plant parts of sesame were enhanced under various $\mathrm{S}$ treatments $\left(\mathrm{S}_{0}, \mathrm{~S}_{20}\right.$, $\mathrm{S}_{40}$, and $\mathrm{S}_{60}$ ), consistently with previously reported trends in 


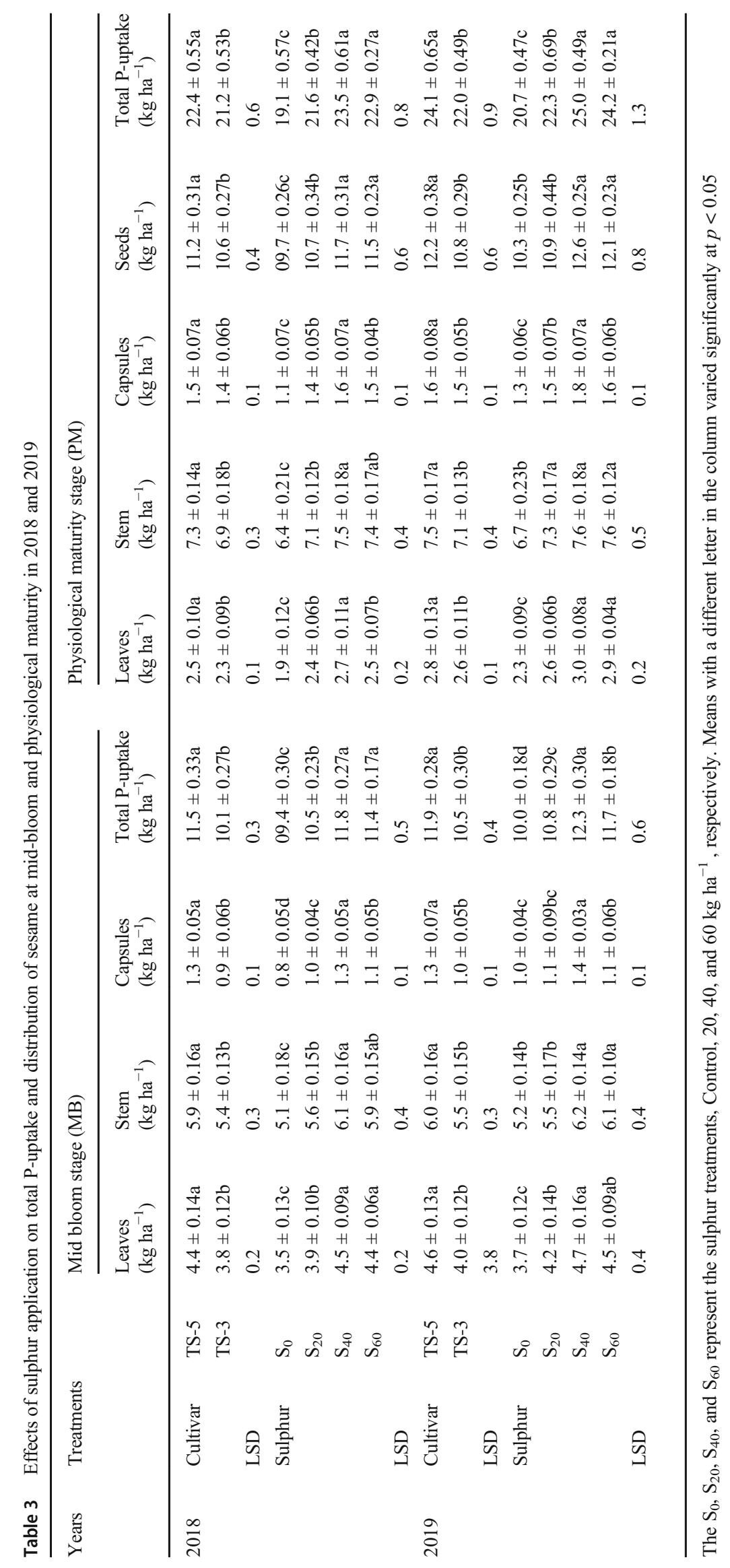




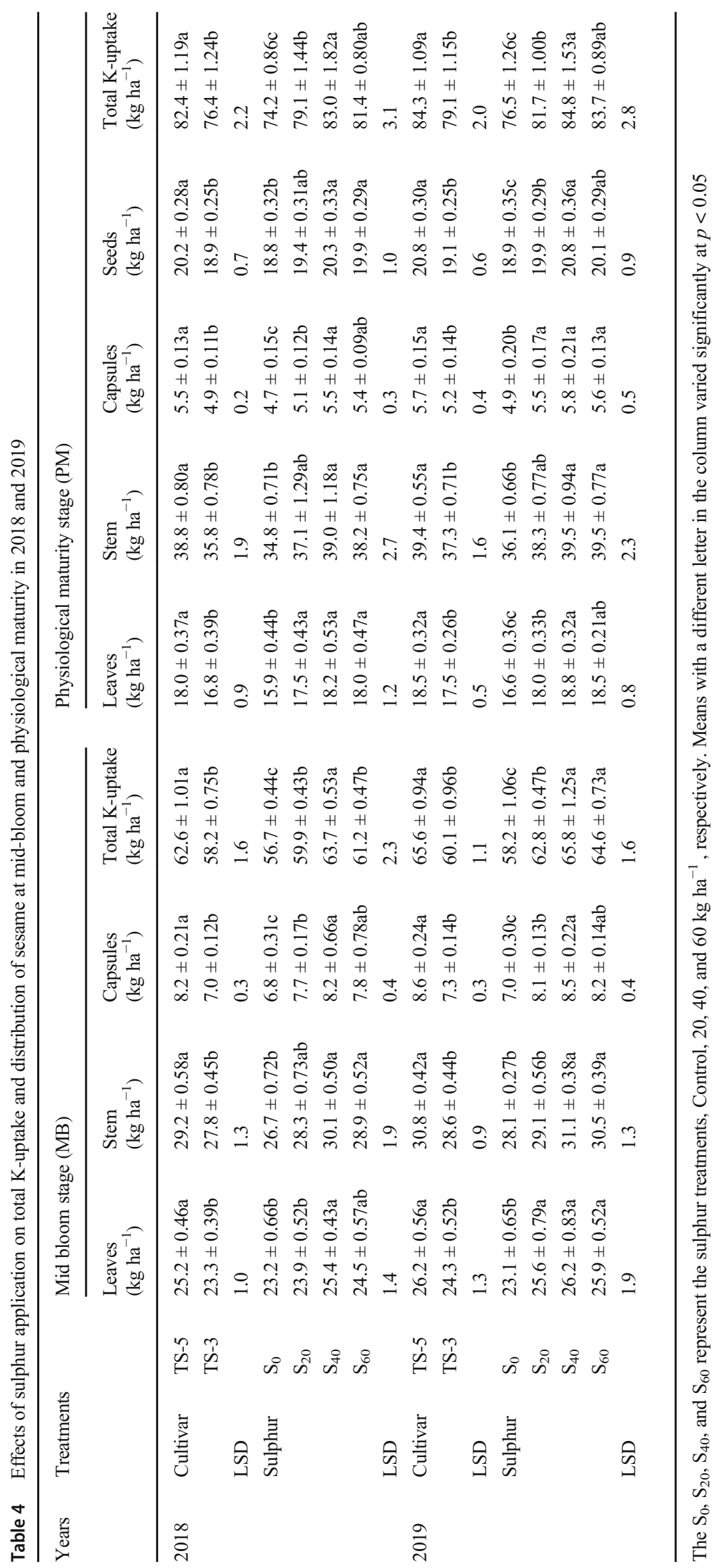




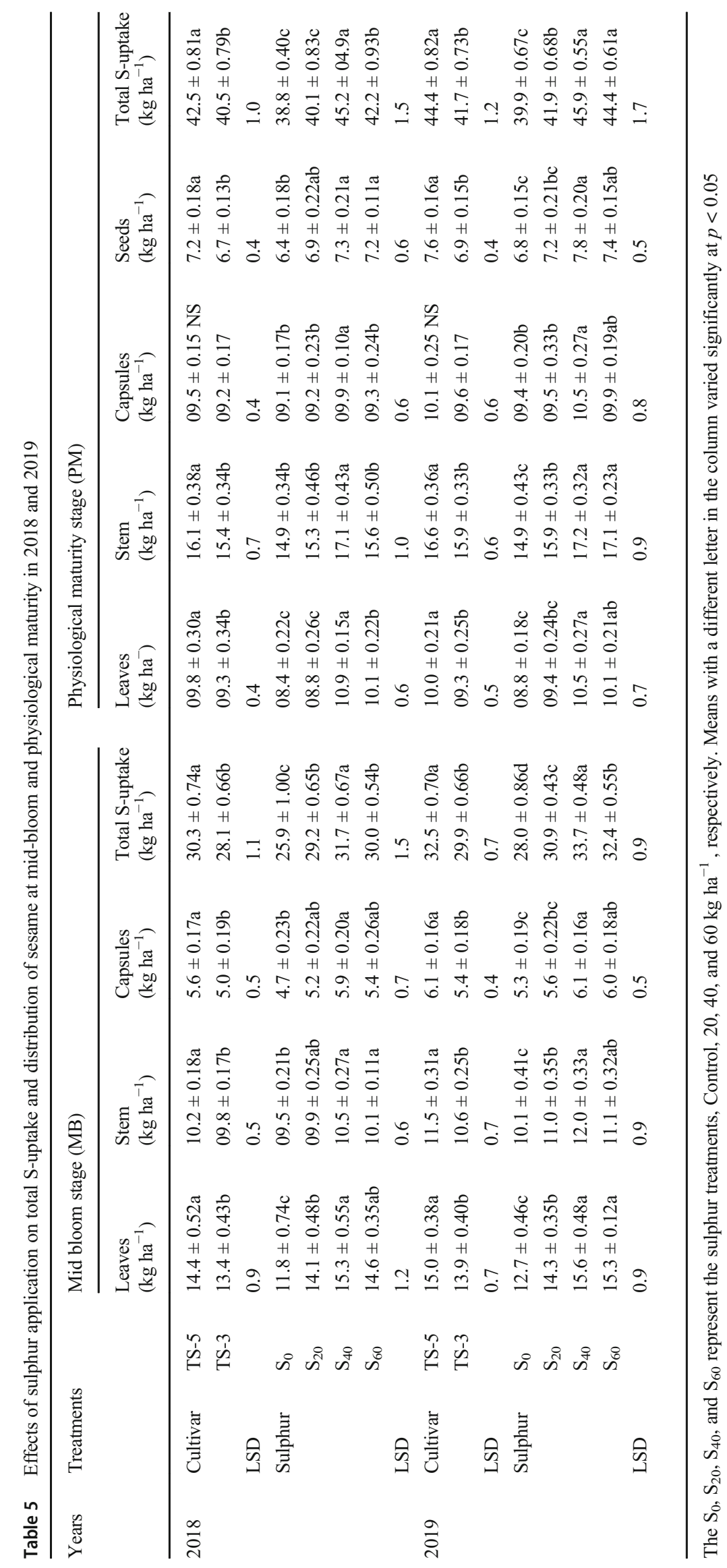



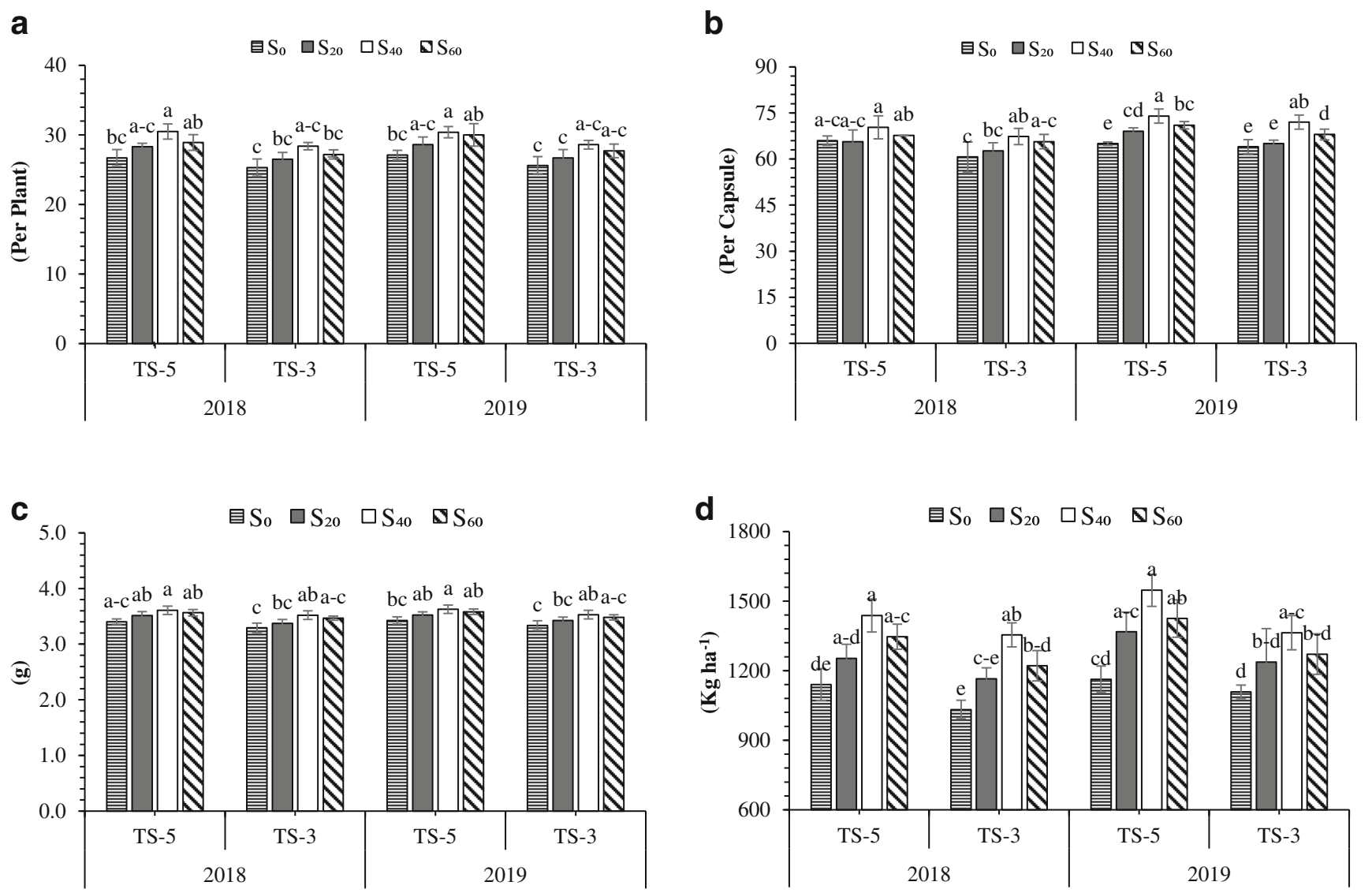

Fig. 4 Number of capsules per plant (a), number of seeds per capsule (b), thousand seed weight (c), and seed yield (d) of sesame in 2018 and 2019 . The $\mathrm{S} 0, \mathrm{~S} 20, \mathrm{~S} 40$, and S60 represent the sulphur treatments, Control, 20, 40, and $60 \mathrm{~kg} \mathrm{ha}^{-1}$, respectively

sesame (Raza et al. 2018b; Couch et al. 2017). It was confirmed in previous studies that low $\mathrm{S}$ availability significantly abate the biomass accumulation in sesame plants (Shah et al. 2013; Raza et al. 2018b). However, our study showed that the $\mathrm{S}$ application to the sesame plants at the rate of $40 \mathrm{~kg} \mathrm{ha}^{-1}$ greatly enhanced the biomass production and distribution as compared to other treatments. This increase might be

Table 6 Economic analysis for different sesame cultivars and Sulphur treatments in 2018 and 2019

\begin{tabular}{lllll}
\hline Treatments & & \multicolumn{2}{l}{ Net income $\left(\mathrm{US} \$ \mathrm{ha}^{-1}\right)$} \\
\cline { 3 - 5 } & & 2018 & 2019 & Average \\
\hline \multirow{2}{*}{ Cultivar } & TS-5 & 584.3 & 575.0 & 579.7 \\
& TS-3 & 511.7 & 491.1 & 501.4 \\
& $\mathrm{~S}_{0}$ & 434.7 & 420.7 & 427.7 \\
& $\mathrm{~S}_{20}$ & 512.1 & 518.3 & 515.2 \\
& $\mathrm{~S}_{40}$ & 631.8 & 603.2 & 617.5 \\
& $\mathrm{~S}_{60}$ & 560.5 & 542.8 & 551.6 \\
\hline
\end{tabular}

The $\mathrm{S}_{0}, \mathrm{~S}_{20}, \mathrm{~S}_{40}$, and $\mathrm{S}_{60}$ represent the sulphur treatments, Control, 20, 40, and $60 \mathrm{~kg} \mathrm{ha}^{-1}$, respectively. The exchange rate for the US dollar was 138.9 and 155.3 Pakistani Rupee (PKR) in 2018 and 2019, respectively associated with optimum S availability to sesame plants (Raza et al. 2018b), which increases the photosynthesis ability of sesame due to the enhanced chlorophyll biosynthesis and Rubisco activity (Resurreccion et al. 2001; Singh et al. 2018), and improves the nutrient uptake due to increased water flow from the rhizosphere, (Muchow and Davis 1988; Elliott et al. 1997). Moreover, the biomass partitioning also followed the previously reported trend, where the vegetative parts had the maximum proportion of biomass at the start of the seed filling phase (MB) while at the end of the seed filling phase (PM), reproductive parts showed a significant increase in the proportion of accumulated biomass (Narayanan and Reddy 1982; Atta and Van Cleemput 1988; Couch et al. 2017; Mehmood et al. 2021). The possible reason for this improvement in reproductive biomass was the increased assimilate production by sesame stems and capsules which retained longer than leaves, and remobilization of assimilates from senescing leaves towards the capsules and developing seed tissues. Such trends of assimilate production by capsules and remobilization from leaves were reported earlier in filed pea and soybean (Flinn and Pate 1970; Andrews and Svec 1975, 1976). Hence, it is convincible that photosynthesis by sesame stems and capsules, and remobilization from senescing leaves contributed to increasing the reproductive biomass at 
maturity. However, the photosynthetic ability of sesame stems and capsules is still unknown and warrants detailed investigation. Hence, our results indicate that from MB to PM, sesame plants had the chance to enhance the biomass accumulation and partitioning to plant organs, if the conditions are favorable during growing period, such as improved nutrient availability and uptake, which can be maintained through an optimum level of S application, as observed during this study.

We determined that all the treatments significantly altered the total $\mathrm{N}, \mathrm{P}, \mathrm{K}$, and $\mathrm{S}$ accumulation and distribution into different plant parts (leaves, stem, capsules, and seeds) of sesame at MB and PM, depending on the nutrient requirements (low and high) in various parts. In the past, researchers have inferred and regarded seeds as the most active and vital sink for photoassimilate and nutrients during the reproductive phase (Couch et al. 2017; Kitonyo et al. 2018). Likewise, N, P, $\mathrm{K}$, and $\mathrm{S}$ uptake in leaves and capsules reduced from MB to $\mathrm{PM}$, suggesting that uptake and remobilization of these nutrients to other plant parts of sesame, possibly in seeds and stems were increased. Additionally, partitioning of N, P, K, and S in leaves is critical in maintaining the higher rate of photoassimilate production, and accumulation of these nutrients depends on the photosynthetic capacity of plants, which governs the nutrient allocation patterns in various plant organs (Raza et al. 2020). In past studies, scientists have reported that low $\mathrm{S}$ availability can reduce the total uptake of nutrients especially N, P, K, and S in plants (Abdallah et al. 2010; Motior et al. 2011; Girondé et al. 2014). Correspondingly, treatment $\mathrm{S}_{40}$ enhanced the $\mathrm{S}$ availability, which might improve the biomass partitioning and carbohydrates translocation in roots as well and ultimately enhance the nutrients uptake (Henry and Raper Jr 1991; Abdallah et al. 2010). Previously, scientists have reported that increased $\mathrm{S}$ availability due to an adequate supply of S could improve the N-uptake during the reproductive growth, which ultimately increases the seed yield of crops (Abdallah et al. 2010; Motior et al. 2011), as noted in this study. Compared with N-uptake, Puptake occurs throughout the growing period of crops (Batten 1992), whereas a substantial amount of $P$ accumulation was documented during seed filling (Papakosta 1994), as observed in our experiment. Similarly, an increase in Kuptake and S-uptake in response to $\mathrm{S}$ fertilization is also reported in several investigations (Motior et al. 2011; Raza et al. 2018a, 2018b). Thus, enhanced S availability through optimum S fertilization could enhance the nutrients accumulation, distribution, and uptake in various plant organs by maintaining a high supply of assimilates and improving the microenvironment of crop plants.

Application of S fertilizer at the rate of $40 \mathrm{~kg} \mathrm{ha}^{-1}\left(\mathrm{~S}_{40}\right)$ produced the highest seed yield, with an increment of $28 \%$, as compared to control $\left(\mathrm{S}_{0}\right)$. Furthermore, we also observed that different $S$ levels significantly increased the number of capsules per plant, number of seeds per capsule, and thousand seed weight, while maximum values for these yield components were observed under $\mathrm{S}_{40}$ treatment during both years. Therefore, the highest sesame yield was ascribed to heavier sesame seeds and greater capsules number per plant and seeds per capsule. Another reason for these increments might be the availability of supplementary carbohydrates and photoassimilate due to enhanced photosynthetic capacity of sesame under optimum $\mathrm{S}$ availability which increased the biomass and nutrient accumulation that ultimately lead to improvements in seed yield and yield components of sesame (Raza et al. 2018b). Our results were consistent with earlier reported findings where an optimum $\mathrm{S}$ application $\left(40-50 \mathrm{~kg} \mathrm{ha}^{-1}\right)$ enhanced the seed yield of sesame (Shah et al. 2013; Raza et al. 2018a, 2018b). Hence, adequate $\mathrm{S}$ availability during seed filling could improve the seed yield of sesame by improved accumulation and distribution of dry matter and nutrients in plant organs.

The economic analysis of the current study revealed that in comparison with control, higher net returns by $44 \%$ were achieved under the $\mathrm{S}_{40}$ treatment. Farming communities only adopt strategies that can provide greater yield and net economic returns for the farmers (Raza et al. 2018b). Hence, treatment $\mathrm{S}_{40}$ increased the dry matter accumulation, nutrient uptake of $\mathrm{N}, \mathrm{P}, \mathrm{K}$, and $\mathrm{S}$, which ultimately improved the sesame productivity and provided higher net returns for farmers.

\section{Conclusion}

This research provided evidence for different patterns of biomass accumulation and nutrient uptake $(\mathrm{N}, \mathrm{P}, \mathrm{K}$, and $\mathrm{S})$, and their partitioning in plant organs of sesame at the mid-bloom and physiological maturity under different $\mathrm{S}$ treatments. Based on our research, results revealed that greater dry matter production, nutrient uptake, and seed yield is possible in sesame with an optimum $\left(\mathrm{S}_{40}=40 \mathrm{~kg} \mathrm{ha}^{-1}\right)$ amount of S application, which could also improve the net economic returns for the farmers. To the best of our knowledge, this research is the first to report the effects of S application on nutrient uptake and partitioning in sesame. However, further research is warranted to completely understand the mechanisms regulating the increased nutrient uptake, specifically during the seed filling phase of sesame.

Acknowledgements This study was supported by the Pakistan Agricultural Research Council (PARC). Muhammad Zeeshan Mehmood thanks the Ministry of Education Pakistan for providing the scholarship for his studies.

Funding Open access funding provided by Swedish University of Agricultural Sciences. 
Data availability All data is available in this article.

Code availability No codes are used.

Declarations This research work does not involve humans or animals as research material.

Conflict of interest The authors declare that they have no competing interests.

Open Access This article is licensed under a Creative Commons Attribution 4.0 International License, which permits use, sharing, adaptation, distribution and reproduction in any medium or format, as long as you give appropriate credit to the original author(s) and the source, provide a link to the Creative Commons licence, and indicate if changes were made. The images or other third party material in this article are included in the article's Creative Commons licence, unless indicated otherwise in a credit line to the material. If material is not included in the article's Creative Commons licence and your intended use is not permitted by statutory regulation or exceeds the permitted use, you will need to obtain permission directly from the copyright holder. To view a copy of this licence, visit http://creativecommons.org/licenses/by/4.0/.

\section{References}

Abdallah M, Dubousset L, Meuriot F, Etienne P, Avice J, Ourry A (2010) Effect of mineral sulphur availability on nitrogen and sulphur uptake and remobilization during the vegetative growth of Brassica napus L. J Exp Bot 61:2635-2646. https://doi.org/10.1093/jxb/erq096

Abiodun OA 2017 The role of oilseed crops in human diet and industrial use. Oilseed crops: yield and adaptations under environmental stress, 249-263. https://doi.org/10.1002/9781119048800

Andrews A, Svec L (1975) Photosynthetic activity of soybean pods at different growth stages compared to leaves. Can J Plant Sci 55:501505. https://doi.org/10.4141/cjps75-076

Andrews A, Svec L (1976) Pod and leaf photosynthesis and disease incidence in soybean (Glycine max (L.) Merr.) with potassium fertilization. Commun. Soil Sci. Plant Anal 7:345-363. https://doi.org/ 10.1080/00103627609366647

Arduini I, Masoni A, Ercoli L, Mariotti M (2006) Grain yield, and dry matter and nitrogen accumulation and remobilization in durum wheat as affected by variety and seeding rate. Eur J Agron 25: 309-318. https://doi.org/10.1016/j.eja.2006.06.009

Atta SK, Van Cleemput O (1988) Field study of the fate of labelled fertilizer ammonium-N applied to sesame and sunflower in a sandy soil. Plant Soil 107:123-126. https://doi.org/10.1007/BF02371553

Batten GD (1992) A review of phosphorus efficiency in wheat. Plant Soil 146:163-168. https://doi.org/10.1007/BF00012009

Carciochi WD, Wyngaard N, Divito GA, Calvo NIR, Cabrera ML, Echeverría HE (2016) Diagnosis of sulfur availability for corn based on soil analysis. Biol. Fertility Soils 52:917-926. https://doi.org/10. 1007/s00374-016-1130-8

Carciochi WD, Salvagiotti F, Pagani A, Calvo NIR, Eyherabide M, Rozas HRS, Ciampitti IA (2020) Nitrogen and sulfur interaction on nutrient use efficiencies and diagnostic tools in maize. Eur J Agron 116:126045. https://doi.org/10.1016/j.eja.2020.126045

Couch A, Jani A, Mulvaney M, Hochmuth G, Bennett J, Gloaguen R, Langham R, Rowland D (2017) Nitrogen accumulation, partitioning, and remobilization by diverse sesame cultivars in the humid southeastern USA. Field Crop Res 203:55-64. https://doi. org/10.1016/j.fcr.2016.12.012
Elliott D, Reuter D, Reddy G, Abbott R (1997) Phosphorus nutrition of spring wheat (Triticum aestivum L.). 1. Effects of phosphorus supply on plant symptoms, yield, components of yield, and plant phosphorus uptake. Aust J Agric Res 48:855-868. https://doi.org/10. 1071/A96159

Eriksen J (2009) Soil sulfur cycling in temperate agricultural systems. Adv Agron 102:55-89. https://doi.org/10.1016/S0065-2113(09) 01002-5

Estefan G, Sommer R, Ryan J (2013) Methods of soil, plant, and water analysis. A manual for the West Asia and North Africa region 3:65119

FAO 2017 The future of food and agriculture- Trends and challenges. Agriculture Organization of the United Nations Rome

Flinn A, Pate J (1970) A quantitative study of carbon transfer from pod and subtending leaf to the ripening seeds of the field pea (Pisum arvense L.). J Exp Bot 21:71-82. https://doi.org/10.1093/jxb/21.1. 71

Girondé A, Dubousset L, Trouverie J, Etienne P, Avice J-C (2014) The impact of sulfate restriction on seed yield and quality of winter oilseed rape depends on the ability to remobilize sulfate from vegetative tissues to reproductive organs. Front Plant Sci 5:695. https:// doi.org/10.3389/fpls.2014.00695

Haneklaus S, Bloem E, Schnug E (2007) Sulfur interactions in crop ecosystems. Sulfur in Plants An Ecological Perspective. Springer: 17-58. https://doi.org/10.1007/978-1-4020-5887-5_2

Henry LT, Raper CD Jr (1991) Soluble carbohydrate allocation to roots, photosynthetic rate of leaves, and nitrate assimilation as affected by nitrogen stress and irradiance. Bot Gaz 152:23-33. https://doi.org/ $10.1086 / 337859$

Iqbal A, Hidayat Z (2016) Potassium management for improving growth and grain yield of maize (Zea mays L.) under moisture stress condition. Sci Rep 6:34627. https://doi.org/10.1038/srep34627

Islam F, Gill RA, Ali B, Farooq MA, Xu L, Najeeb U, Zhou W 2016 Sesame. Breeding Oilseed Crops for Sustainable Production. Elsevier, pp. 135-147. https://doi.org/10.1016/B978-0-12-8013090.00006-9

Kitonyo OM, Sadras VO, Zhou Y, Denton MD (2018) Nitrogen supply and sink demand modulate the patterns of leaf senescence in maize. Field Crop Res 225:92-103. https://doi.org/10.1016/j.fcr.2018.05. 015

Langham DR 2007 Phenology of sesame. Issues in New Crops and New Uses, Janick \& Whipkey, eds., ASHS Press, Alexandria, VA, 144182

Li L, Sun J, Zhang F, Li X, Yang S, Rengel Z (2001) Wheat/maize or wheat/soybean strip intercropping: I. Yield advantage and interspecific interactions on nutrients Field Crops Res 71:123-137. https:// doi.org/10.1016/S0378-4290(01)00156-3

Mehmood MZ, Qadir G, Afzal O, Din AMU, Raza MA, Khan I, Hassan MJ, Awan SA, Ahmad S, Ansar M, 2021. Paclobutrazol improves sesame yield by increasing dry matter accumulation and reducing seed shattering under rainfed conditions. International Journal of Plant Production, 1-13. https://doi. org/10.1007/s42106-021-00132-w

Motior M, Abdou A, Al Darwish FH, El-Tarabily KA, Awad MA, Golam F, Sofian-Azirun M (2011) Influence of elemental sulfur on nutrient uptake, yield and quality of cucumber grown in sandy calcareous soil. Aust J Crop Sci 5:1610-1615

Muchow R, Davis R (1988) Effect of nitrogen supply on the comparative productivity of maize and sorghum in a semi-arid tropical environment II. Radiation interception and biomass accumulation Field Crops Res 18:17-30. https://doi.org/10.1016/0378-4290(88) 90056-1

Narayanan A, Reddy KB (1982) Growth, development and yield of sesame (Sesamum indicum L.) cultivars. Field Crop Res 5:217-224. https://doi.org/10.1016/0378-4290(82)90024-7 
Papakosta DK (1994) Phosphorus accumulation and translocation in wheat as affected by cultivar and nitrogen fertilization. J Agron Crop Sci 173:260-270. https://doi.org/10.1111/j.1439-037X.1994. tb00563.x

Prystupa P, Savin R, Slafer GA (2004) Grain number and its relationship with dry matter, $\mathrm{N}$ and $\mathrm{P}$ in the spikes at heading in response to $\mathrm{N} \times \mathrm{P}$ fertilization in barley. Field Crop Res 90:245-254. https://doi.org/ 10.1016/j.fcr.2004.03.001

Rahman M, Dejiménez MM 2016. Designer Oil Crops. Breeding Oilseed Crops for Sustainable Production. Elsevier, pp. 361-376. https://doi. org/10.1016/B978-0-12-801309-0.00015-X

Rani K, Sharma K, Nagasri K, Srinivas K, Vishnu Murthy T, Maruthi Shankar G, Korwar G, Sridevi Sankar K, Madhavi M, Kusuma Grace J (2009) Response of sunflower to sources and levels of sulfur under rainfed semi-arid tropical conditions. Commun Soil Sci Plant Anal 40:2926-2944. https://doi.org/10.1080/00103620903175389

Raza MA, Feng LY, Manaf A, Wasaya A, Ansar M, Hussain A, Khalid MHB, Iqbal N, Xi ZJ, Chen YK (2018a) Sulphur application increases seed yield and oil content in sesame seeds under rainfed conditions. Field Crop Res 218:51-58. https://doi.org/10.1016/j. fcr.2017.12.024

Raza MA, Feng LY, Iqbal N, Manaf A, Khalid MHB, Ur Rehman S, Wasaya A, Ansar M, Billah M, Yang F (2018b) Effect of sulphur application on photosynthesis and biomass accumulation of sesame varieties under rainfed conditions. Agronomy 8:149. https://doi.org/ 10.3390/agronomy8080149

Raza MA, Feng LY, van der Werf W, Iqbal N, Khan I, Hassan MJ, Ansar M, Chen YK, Xi ZJ, Shi JY (2019) Optimum leaf defoliation: a new agronomic approach for increasing nutrient uptake and land equivalent ratio of maize soybean relay intercropping system. Field Crop Res 244:107647. https://doi.org/10.1016/j.fcr.2019.107647

Raza MA, van der Werf W, Ahmed M, Yang W (2020) Removing top leaves increases yield and nutrient uptake in maize plants. Nutr Cycl Agroecosyst 118:57-73. https://doi.org/10.1007/s10705-02010082-w

Resurreccion AP, Makino A, Bennett J, Mae T (2001) Effects of sulfur nutrition on the growth and photosynthesis of rice. Soil Sci Plant Nutr 47:611-620. https://doi.org/10.1080/00380768.2001. 10408424

Sahoo P, Brar A, Sharma S (2018) Effect of methods of irrigation and sulphur nutrition on seed yield, economic and bio-physical water productivity of two sunflower (Helianthus annuus L.) hybrids. Agric. Water Manage 206:158-164. https://doi.org/10.1016/j. agwat.2018.05.009

Salvagiotti F, Castellarín JM, Miralles DJ, Pedrol HM (2009) Sulfur fertilization improves nitrogen use efficiency in wheat by increasing nitrogen uptake. Field Crop Res 113:170-177. https://doi.org/10. 1016/j.fcr.2009.05.003

Scherer HW (2001) Sulphur in crop production. Eur J Agron 14:81-111. https://doi.org/10.1016/S1161-0301(00)00082-4

Shah MA, Manaf A, Hussain M, Farooq S, Zafar-ul-Hye M 2013 Sulphur fertilization improves the sesame productivity and economic returns under rainfed conditions. International Journal of Agriculture and Biology 15

Sinclair TR, Rufty TW, Lewis RS (2019) Increasing photosynthesis: unlikely solution for world food problem. Trends Plant Sci 24: 1032-1039. https://doi.org/10.1016/j.tplants.2019.07.008

Singh R, Parihar P, Prasad SM (2018) Sulfur and calcium simultaneously regulate photosynthetic performance and nitrogen metabolism status in As-challenged Brassica juncea L. seedlings. Front Plant Sci 9: 772. https://doi.org/10.3389/fpls.2018.00772

Steinke K, Rutan J, Thurgood L (2015) Corn response to nitrogen at multiple sulfur rates. Agron J 107:1347-1354. https://doi.org/10. 2134/agronj14.0424

Verma BC, Swaminathan K, Sud K (1977) An improved turbidimetric procedure for the determination of sulphate in plants and soils. Talanta 24:49-50. https://doi.org/10.1016/0039-9140(77)80185-9

Vouillot M, Devienne-Barret F (1999) Accumulation and remobilization of nitrogen in a vegetative winter wheat crop during or following nitrogen deficiency. Ann Bot 83:569-575. https://doi.org/10.1006/ anbo.1999.0861

Xia H-Y, Wang Z-G, Zhao J-H, Sun J-H, Bao X-G, Christie P, Zhang FS, Li L (2013) Contribution of interspecific interactions and phosphorus application to sustainable and productive intercropping systems. Field Crop Res 154:53-64. https://doi.org/10.1016/j.fcr.2013. 07.011

Zargar SM, Gupta N, Nazir M, Mir RA, Gupta SK, Agrawal GK, Rakwal R (2016) Omics-A New Approach to Sustainable Production. Breeding oilseed crops for sustainable production. Elsevier, pp. 317-344. https://doi.org/10.1016/B978-0-12-801309-0.00013-6

Zhang Z, Sun K, Lu A, Zhang X (1999) Study on the effect of S fertilizer application on crops and the balance of S in soil. J Agric Sci 5:25-27 